\title{
The effect of the anterior ganglia on forward movements in the earthworm
}

\author{
JANE E. WARD and JOHN H. DOOLITTLE \\ California State University, Sacramento, Sacramento, California 95819
}

\begin{abstract}
The role of the anterior ganglia in the ability of the earthworm ( $L$. rubellus) to inhibit movement when substrate contact was lost and to move forward was investigated. In Experiment I, worms were observed during the regeneration period following removal of the anterior five segments. A difference $(p=.005)$ was found between the experimental (removal) and control (nonremoval) groups in ability to prevent falling off an elevated platform. The proportion of forward movements for the experimental group increased from an initial low of .31 to .93 over 31 days, while the control group maintained a high proportion (.97) throughout the experiment. Experiment II replicated the first 36-h period of Experiment $I$ and confirmed the finding that the proportion of forward movements for the experimental group declined slowly to a minimum at $24 \mathrm{~h}$, then increased to .21 by $36 \mathrm{~h}$. The results were discussed in relation to Needham's (1957) hypothesis of a posterior hormonal and metabolic integrating center.
\end{abstract}

Bullock and Horridge (1965) have described the various functions of the supraesophageal ganglion (brain) and of the subesophageal ganglion in mediating annelid behaviors. These ganglia appear unnecessary for the earthworm's ability to right itself (Bullock \& Horridge, $1965)$, to learn mazes (Heck, 1920; Yerkes, 1912), to escape from strong light (Doolittle, 1972; Prosser, 1934; Smith, 1902), to escape from an intense heat source (Smith, 1902), or to burrow in loose soil (Focke, 1930).

Loss of the supraesophageal ganglion alone results in reduced reaction to low and moderate levels of illumination (Hess, 1924; Howell, 1939; Nomura, 1926; Prosser, 1934), loss of the ability to inhibit forward movement when contact with the substrate is lost (Janzen, 1931), and in loss of the ability to regenerate lost posterior segments (Bullock \& Horridge, 1965).

Loss of both anterior ganglia results in loss of spontaneity and muscle tone (Bullock \& Horridge, 1965) and in impairment of the ability to move backward (Janzen, 1931).

Smith (1902) reported an interaction between levels of light and bodily contact under conditions of concurrent stimulation for intact worms, but not for worms deprived of their anterior ganglia. Recent experiments by Ratner and Gardner (1968) and by Doolittle (1972), however, have not supported the implication that the anterior ganglia have an effect on this taxic interaction.

It was noticed in Doolittle (1972) that most earthworms without anterior ganglia escaped from light by using backward movements. This finding was unexpected because of Janzen's (1931) suggestion that such worms are deficient in ability to move backward.

One strategy for studying the relationship between these ganglia and earthworm behavior has been to remove the ganglia and observe behavior during the regeneration period. Prosser (1934) used this approach to observe changes in negative phototaxis in regenerating earthworms. Prosser found negative phototaxis to be at a minimum 4 days following ganglia removal. The return of negatively phototaxic behavior closely followed the regeneration of neural tissue. The present study attempted to apply this regeneration strategy to a further study of the role of the anterior ganglia in the control of backward movements and in the ability to inhibit forward movement when substrate contact is lost.

\section{EXPERIMENT I}

\section{Method}

The Ss, 20 mature earthworms (L. rubellus), were selected randomly from a supply obtained locally and assigned to one of two conditions, removal (experimental) or nonremoval (control) of the anterior five segments which contain the supra- and subesophageal ganglia. Preliminary studies have indicated that the behavior of sham-operated worms (those in which the dorsal skin was cut at the fifth segment) did not differ from that of intact worms. Therefore, no attempt was made to provide a sham-operated control group in the present experiment.

After assignment, each $S$ was rinsed in distilled water, and Ss in the experimental group had the anterior five segments removed according to the surgical procedure described by Ratner and Stein (1965). The Ss in the control group were similarly handled, but no surgery was performed. Each $S$ was maintained at $70^{\circ}-75^{\circ} \mathrm{F}$ throughout the experiment in an individual 1-pint plastic carton, half filled with dead and decaying leaves. Distilled water was added to the cartons as necessary to prevent desiccation, and a small amount of cornmeal was provided as additional food.

The experimental apparatus consisted of a $1 \times 12 \times 1 / 4$ in. piece of wood, which was supported by a 6-in.-long dowel to form a 1 $x 12$ in. elevated platform. The upper surface and sides of the platform were covered with a strip of paper towel moistened with distilled water. The paper was replaced daily.

Each $S$ was observed on the experimental apparatus at approximately 10,16 , and $24 \mathrm{~h}$ following surgery and thereafter at 24-h intervals for 30 days. Ss were run individually and in random order. For each trial, each $\mathrm{S}$ was gently transferred with the blade of a table knife from its container to the inside of a 


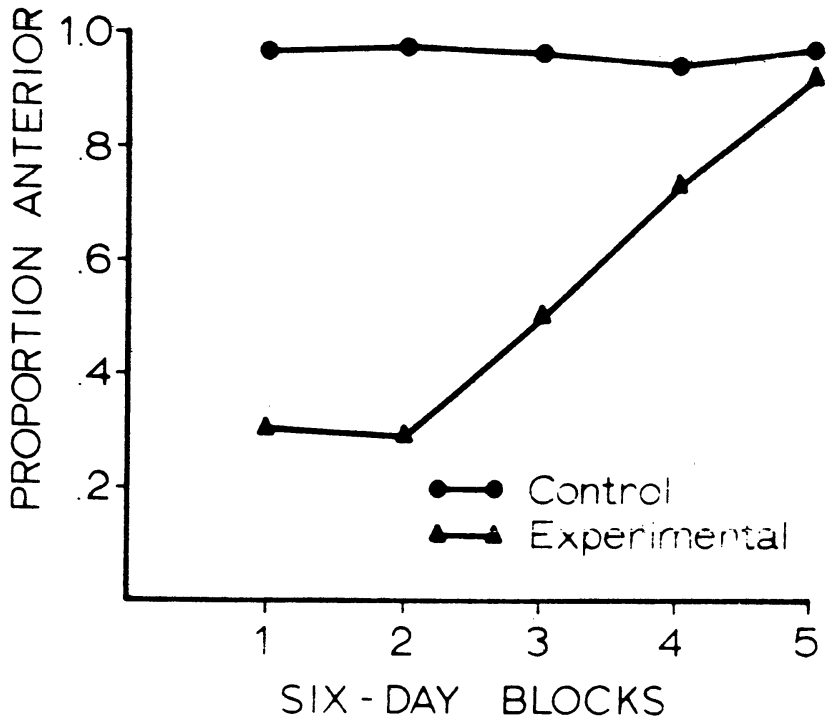

Fig. 1. The mean proportions of anterior movements to total movements over 6-day blocks of trials.

plastic cylinder which had a 1 -in. diam and a 3/8-in. height and was positioned on the center of the paper-covered surface. This procedure had been found in a preliminary study to reduce the thrashing response which characterizes earthworms when handled. After 10-15 sec, the cylinder was carefully lifted from around the $S$, initiating the trial. Each anterior (head-originating) and posterior (tail-originating) movement involving at least one-third of the body was then recorded. A withdrawal fiom the edge was recorded whenever one or more segments regained contact with the surface after having crawled past the edge. The trial was terminated when either the $S$ dropped off the platform or $300 \mathrm{sec}$ had elapsed. All observations after the first $24 \mathrm{~h}$ were made at night. and room illumination was provided by a $25-\mathrm{W}$ ruby red bulb suspended 18 in. above the platform. The experiment was terminated after 31 days, at which time physiological and behavioral regeneration appeared to be complete.

\section{Results}

All 10 experimental Ss and 4 of the 10 control Ss dropped off the platform one or more times during the experiment. This difference in dropoff frequency has a significance probability of .005 on the Fisher exact probability test (Siegel, 1956).

As shown in Fig. 1, control Ss maintained a consistently high proportion (.97) of anterior movements. Experimental Ss increased their proportion of anterior movements from a low initial level (.31) to a level (.93) similar to that of the controls.

Figure 2 shows that the experimental group displayed a gradual decline in the proportion of anterior movements over the first 24-h period following surgery, then increased the proportion of forward movements to .26 by $48 \mathrm{~h}$. A two-factor analysis of variance (Winer, 1962) revealed a significant difference $(F=72.12, \mathrm{df}=$ $1 / 72, p<.01$ ) in proportion of anterior movements between the two groups and a significant interaction $(F$
$=2.94 . \mathrm{df}=3 / 72 . \mathrm{p}<.05)$ between group and time since surgery.

\section{Discussion}

The difference between the experimental and control groups in dropoff frequency $(p=.005)$ strongly supports Janzen's (1931) finding that worms deprived of their anterior ganglia are deficient in ability to inhibit forward movement when contact with the substrate is lost. However, the observation that the experimental group initially makes more posterior than anterior movements is not consistent with Janzen's (1931) suggestion that the ability to move backward is lost. The present findings suggest that in the absence of the anterior ganglia a posterior gradient of dominance is revealed.

A posterior gradient of metabolic activity in earthworms is well established (Hyman, 1916; O'Brien, 1957; Watanabe, 1927). Needham (1957) has interpreted these and other data as suggesting the presence of a posterior metabolic and hormonal integrating center. If Needham's "posterior penultimate control center" in fact exists, it would account for the results of this experiment as follows: The decline of proportion of anterior movements over the first $24 \mathrm{~h}$ reflects the establishment of posterior dominance over the organism. The gradualness of this decline could reflect either some injury shock phenomenon or perhaps the dissipation of neurosecretions from the $b$ cells of the supraesophageal ganglion (Hubl, 1953). Very little is known of the chemical nature of the products of these secreting cells (Laverack, 1963). After this initial period of decline, however, regeneration of neural tissue begins (Stephenson, 1930) and gradually the anterior ganglia regain control of movements.

Because the findings presented in Fig. 2 were

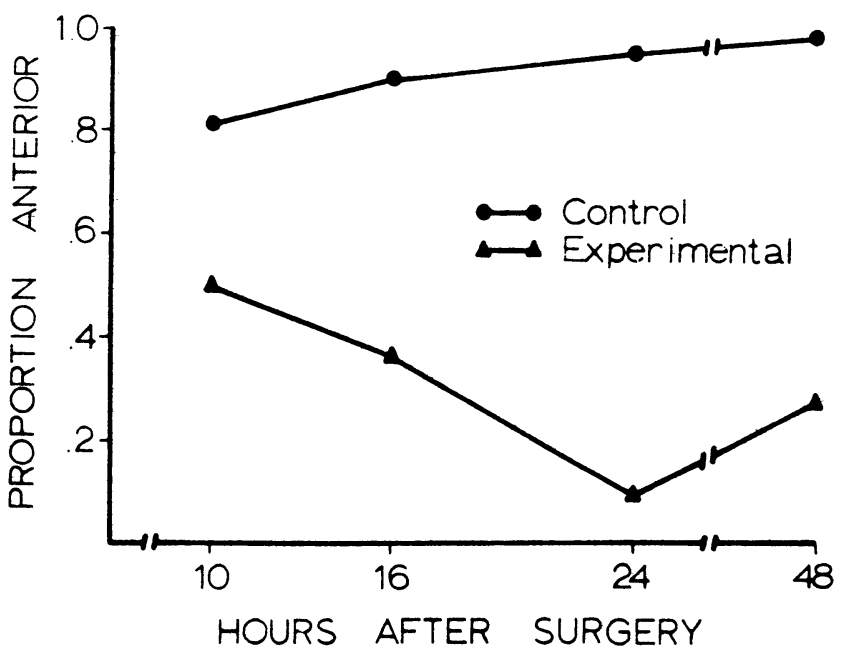

Fig. 2. The mean proportions of anterior movements at four time intervals following surgical removal of the five anterior segments. 
unexpected, it was decided to replicate the initial $36 \mathrm{~h}$ of Experiment I.

\section{EXPERIMENT II}

\section{Method}

As in Experiment I, 20 mature earthworms were assigned randomly to one of two groups, removal (experimental) or nonremoval (control) of the anterior five segments. The apparatus and procedure for this experiment were also the same as in Experiment I, except that observations were made every $2 \mathrm{~h}$ for the first $24 \mathrm{~h}$.

\section{Results}

As shown in Fig. 3, the experimental group displayed a decline in the proportion of anterior movements over the first 24-h period following surgery, then increased to .21 at the 36-h observation. A two-factor analysis of variance (Winer, 1962) showed a significant difference $(F=819.05, \mathrm{df}=1 / 264, p<.01)$ between groups in proportion of anterior movements, and a significant interaction $(F=6.91, \mathrm{df}=6 / 264, \mathrm{p}<.01)$ between group and time since surgery.

\section{Discussion}

The results of this experiment support those of Experiment I and lend confidence in the stability of the observed phenomena. Confidence in the explanation for the phenomena must, of course, await further research.

One implication of these results is that observers of decerebrate worms may obtain varying results according to the length of time between surgery and observation. For example, differences in results between Doolittle (1972) and Ratner and Gardner (1968) may be due in part to the fact that the time intervals between surgery and study were 8 and $24 \mathrm{~h}$, respectively. Furthermore, many older studies, e.g., Smith (1902), do not specify this time interval, making comparisons difficult. It is only to be expected that as knowledge increases in this area of study further refinements will be made in measurement and reporting.

\section{REFERENCES}

Bullock T. H., \& Horridge, G. A. Structure and function in the nervous systems of invertebrates. San Francisco: Freeman, 1965.

Doolittle, J. H. The role of the anterior ganglia in phototaxis and thigmotaxis in the earthworm. Psychonomic Science, 1972, 27, 151-152.

Focke, F. Experimente und Beobachtungen über die Biologie des Regenwurms, unter besonderer Berucksichtigung der Frage nach der Raumorientierung. Zeitschrift für Wissenschaftliche Zoologie, Abteilung A, 1930, 136, 376-421.

Heck, L. Über die Bildung einer Assoziation beim Regenwurm auf Grund von Dressurversuchen. Lotos, 1920, 67, 168-189.

Hess, W. N. Reactions to light in the earthworm, Lumbricus terrestris, L. Journal of Morphology \& Physiology, 1924, 39. 515-542.

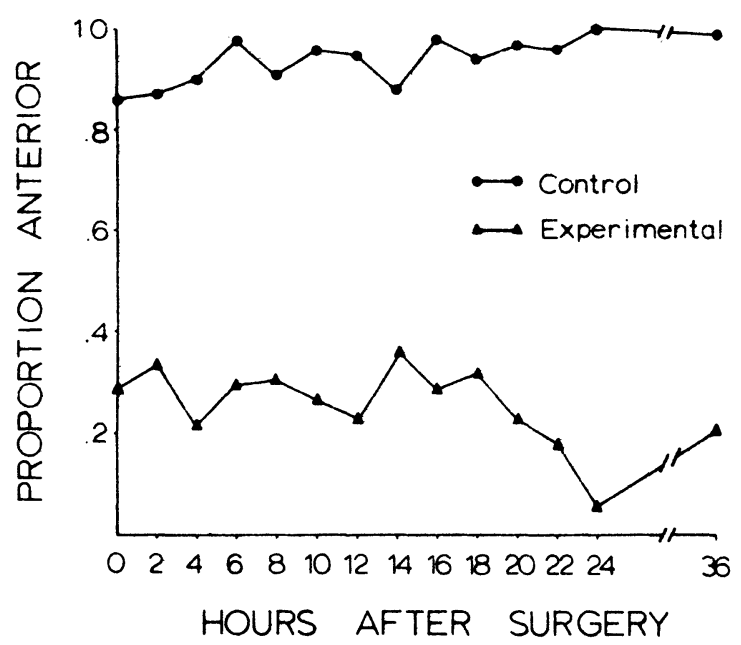

Fig. 3. The mean proportions of anterior movements at four time intervals following surgery.

Howell, C. D. The responses to light in the earthworm, Pheretima agrestris Goto and Hatai, with special reference to the function of the nervous system. Journal of Experimental Zoology, 1939, 81, 231-259.

Hubl, H. Die inkretorischen Zellelemente im Gehirn der lumbriciden. Archiv Entwicklungsmechanismen der Organe, 1953, 146, 421-432.

Hyman, L. H. An analysis of the process of regeneration in certain microdrilous oligochaetes. Journal of Experimental Zoology, 1916, 20, 99-163.

Janzen, R. Beitrage zur Nervenphysiologie der Oligochaeten. Zoologische Jahrbucher Abt für Algemeine Zoologie und Physiologie der Tiere, 1931, 50, 51-150.

Laverack, M. S. The physiology of earthworms. New York: Macmillan, 1963.

Needham, A. E. Components of nitrogenous excreta in the earthworms Lumbricus terrestris, L. and Eisenia foetida (Savigny). Journal of Experimental Biology, 1957, 34, 425-446.

Nomura, E. Effect of light on the movements of the earthworm Allolobophora foetida. Tokohu University Science Reports, Series 4: Biology, 1926, 1, 293-409.

O'Brien, B. R. Evidence in support of an axial metabolic gradient in the earthworm. Australian Journal of Experimental Biology \& Medical Science, 1957, 35, 83-92.

Prosser, C. L. Effect of the central nervous system on responses to light in Eisenia foetida, Sav. Journal of Comparative Neurology, 1934, 59, 61-92.

Ratner, S. C., \& Gardner, L. E. Variables affecting responses of earthworms to light. Journal of Comparative \& Physiological Psychology, 1968, 66, 239-243.

Ratner, S. C., \& Stein, D. G. Responses of worms to light as a function of intertrial interval and ganglion removal. Journal of Comparative \& Physiological Psychology, 1965, 59, 301-305.

Siegel, S. Nonparametric statistics for the behavioral sciences. New York: McGraw-Hill, 1956.

Smith. A. C. The influence of temperature, odors, light, and contact on the movements of the earthworm. American Journal of Physiology, 1902, 6, 459-486.

Stephenson, M. D. The Oligochaeta. London: Oxford University Press, 1930.

Watanabe, Y. On the electrical polarity in the earthworm. Perichaeta communissima Goto et Hatai. Tokohu University Science Reports. 1927, 3. 139-149. 
Winer, B. J. Statistical principles in experimental design. New York: McGraw-Hill. 1962.

Yerkes. R. M. The intelligence of earthworms. Journal of Animal
Behavior. 1912, 2. 332-352.

(Received for publication July 17, 1972: revision received November 28.1972 .) 